\title{
DEVELOPMENT OF ISO 22000 BASED FOOD SAFETY ASSURANCE SYSTEM FOR SRI LANKAN ORTHODOX BLACK TEA INDUSTRY
}

\author{
BY \\ C. V. K. LOKUNARNGODAGE
}

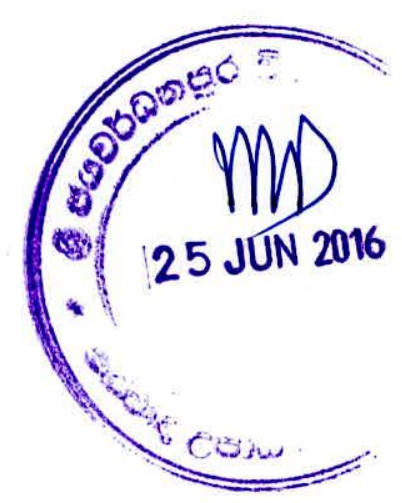

M. Phil 
Development of ISO 22000 Based Food Safety Assurance System for Sri Lankan Orthodox Black Tea Industry

\author{
By \\ C. V. K. Lokunarngodage
}

Thesis submitted to the University of Sri Jayewardenepura for the award of the degree of Master of Philosophy in Food Science \& Technology on 2015. 


\section{DECLARATION}

The work described in this thesis was carried out by me under the supervision of Dr. Indira Wickramasinghe, Department of Food Science \& Technology, Faculty of Applied Sciences, University of Sri Jayewardenepura and Prof. K. K. D. S. Ranaweera, Department of Food Science \& Technology, Faculty of Applied Sciences, University of Sri Jayewardenepura, and a report or this has not been submitted in whole or part to any other university or any other institution for another degree.

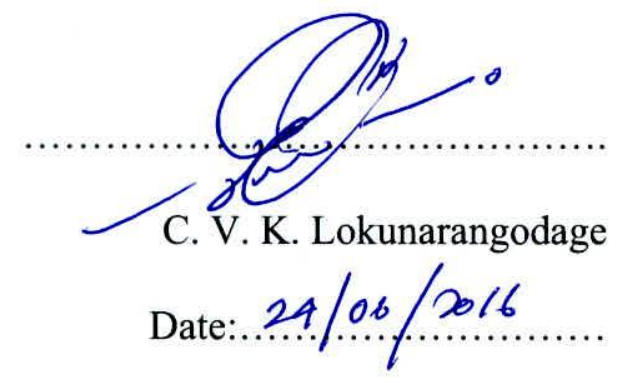


We certify that the candidate is submitting this thesis with all corrections, additions and amendments attended in accordance with the comments and suggestions made by the examiners.

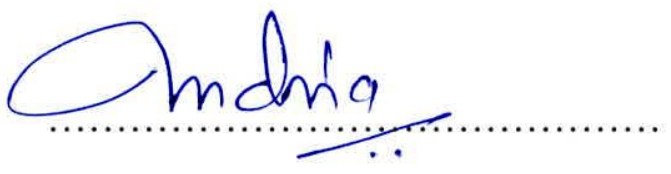

Signature

Supervisor

Dr. Indira Wickramasinghe

Senior Lecturer

Department of Food Science \& Technology Department of Food Science \& Technology

Faculty of Applied Sciences

University of Sri Jayewardenepura

Gangodwila, Nugegoda,

Sri Lanka.

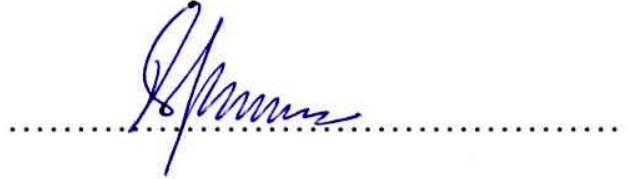

Signature

Supervisor

Prof. K. K. D. S. Ranaweera

Senior Lecturer
University of Sri Jayewardenepura

Gangodwila, Nugegoda,

Sri Lanka. 
We certify that the above statement made by the candidate is true and that this thesis is suitable for submission to the University for the purpose of evaluation.

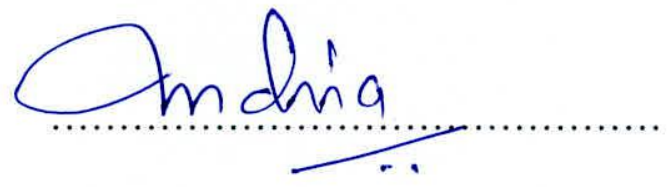

Signature

Supervisor

Dr. Indira Wickramasinghe

Senior Lecturer

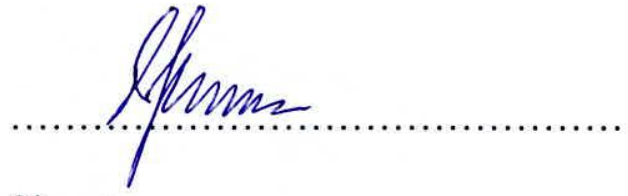

Signature

Supervisor

Prof. K. K. D. S. Ranaweera

Senior Lecturer

Department of Food Science \& Technology Department of Food Science \& Technology

Faculty of Applied Sciences

University of Sri Jayewardenepura

Gangodwila, Nugegoda,

Sri Lanka.
Faculty of Applied Sciences

University of Sri Jayewardenepura

Gangodwila, Nugegoda,

Sri Lanka. 


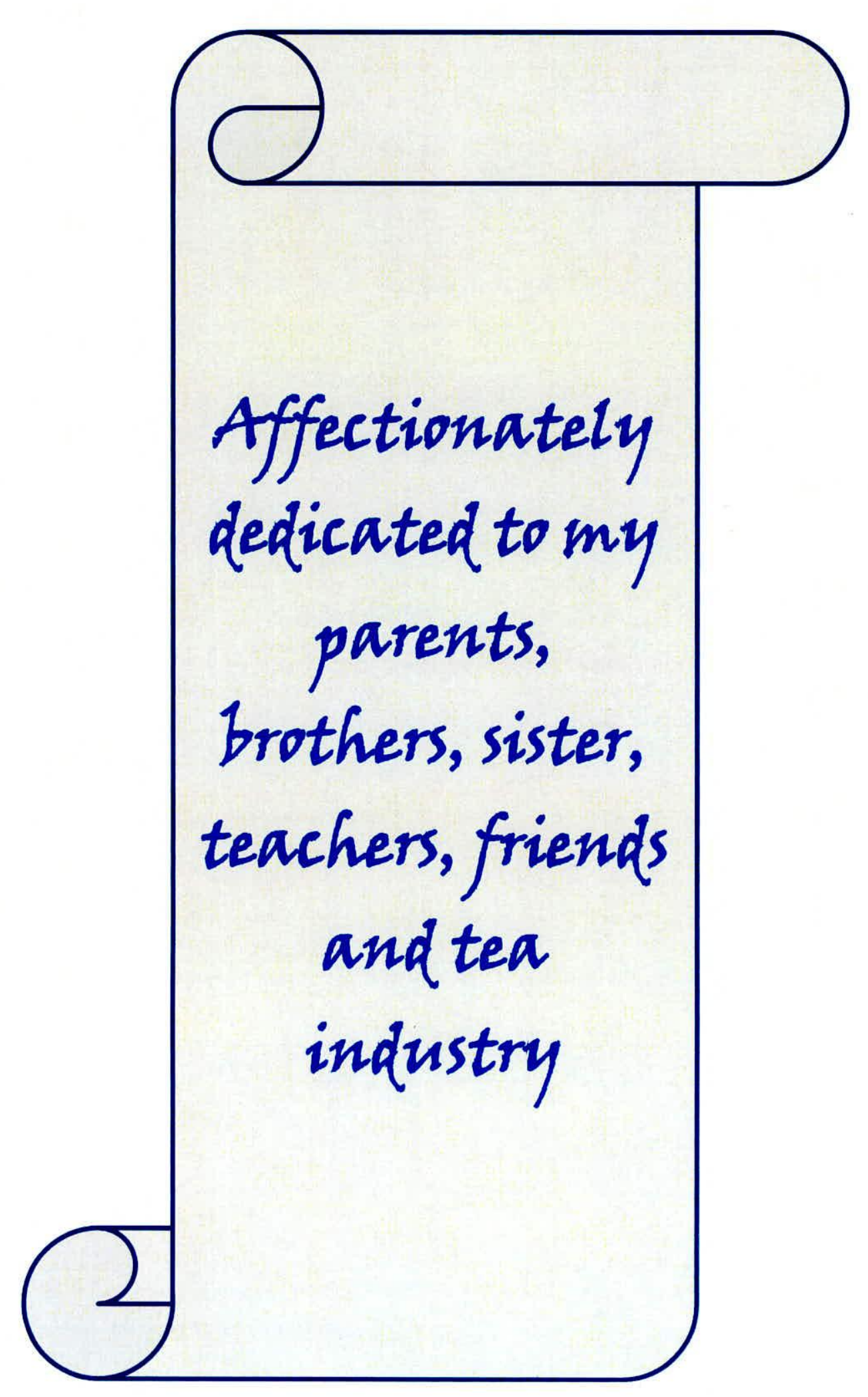




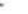




\section{TABLE OF CONTENT}

Table of Content

List of Tables

List of Figures

vi

Acknowledgement

Abbreviation

Abstract

$\mathrm{X}$

CHAPTER 1: INTRODUCTION

CHAPTER 2: LITERATURE REVIEW

$2.1 \quad$ Introduction to tea

2.1.1 Ecology of growing tea 08

2.1.2 Botany of commercial tea plant 09

$\begin{array}{lll}2.2 & \text { History of Ceylon tea } & 10\end{array}$

$\begin{array}{lll}2.3 & \text { Sri Lankan tea statistics } & 12\end{array}$

2.4 Problems encountered in Sri Lankan tea industry 14

$\begin{array}{lll}2.5 & \text { The cost of production } & 14\end{array}$

$\begin{array}{lll}2.6 & \text { Non-financial barriers in tea industry } & 15\end{array}$

$\begin{array}{lll}2.7 & \text { Orthodox black tea manufacturing } & 17\end{array}$

$\begin{array}{lll}2.7 .1 & \text { Tea plucking } & 17\end{array}$

$\begin{array}{lll}2.7 .2 & \text { Withering } & 18\end{array}$

$\begin{array}{ll}\text { 2.7.3 Disruption/Rolling } & 19\end{array}$

$\begin{array}{ll}2.7 .4 & \text { Oxidation/Fermentation } \\ 2.7 .5 & 21\end{array}$

$\begin{array}{lll}2.7 .5 & \text { Firing } & 23\end{array}$

2.7.6 Grading 24

$\begin{array}{lll}2.7 .7 & \text { Bulking } & 25\end{array}$

2.7.8 Packing 25

$\begin{array}{lll}2.7 .9 & \text { Tea Brewing } & 26\end{array}$

$2.8 \quad$ Traceability in tea supply chain 26

$2.9 \quad$ Evolution of ISO standards 29

$\begin{array}{lll}2.9 .1 & \text { ISO 9000:2008 } & 31\end{array}$

2.9.2 Food safety and standards $\quad 32$

2.9.3 HACCP 36

2.9.4 What is ISO 22000:2005? 37 An integrated food safety management system

$\begin{array}{lll}2.10 & \text { Tea Standards } & 50\end{array}$

2.10.1 ISO 3720:2011 50

2.10.2 SLS Standards 51

2.10.3 Product Certification Scheme for Tea (PCST) 52

2.10.4 SLTB Standards 53

$2.115 \mathrm{~S}$ and Ceylon tea 55 
CHAPTER 3: MATERIALS AND METHODS 63

$3.1 \quad$ Gap analysis and internal auditing 63

3.2 Impact of HACCP based FSMS in Sri Lankan tea industry 70

3.3 Evaluation of food safety violation and generic model 72 development

3.4 Synchronization of 5S in ISO 22000:2005 74

$\begin{array}{lll}3.5 & \text { Traceability constrains in tea manufacturing process } & 74\end{array}$

$\begin{array}{lll}3.6 & \text { Bridging the gap in fermentation } & 76\end{array}$

3.6.1 The tea polymerizer trolley - wire frame drawings 77

3.7 Dissemination of information 80

CHAPTER 4: RESULTS AND DISCUSSION $\quad 81$

4.1 Gap Analysis and Audits $\quad 81$

4.1.1 Food safety violations in low grown orthodox black tea 82 manufacturing process

4.1.1.1 Section I: Organization and management responsibilities 83

4.1.1.2 Section II: Establishment design and facilities 87

4.1.1.2.1 Location and surrounding $\quad 89$

4.1.1.2.2 Design and layout $\quad 89$

4.1.1.2.3 Drainage and waste disposal 91

4.1.1.2.4 Sitting of equipment 92

4.1.1.2.5 Condition of floor 92

4.1.1.2.6 Condition of walls, doors and windows 93

4.1.1.2.7 Condition of ceilings and lights 94

4.1.1.2.8 Air quality ventilation 95

4.1.1.2.9 Water supply $\quad 95$

4.1.1.3 Section III: Storage facilities 98

$\begin{array}{ll}\text { 4.1.1.4 Section IV: Distribution facilities } & 101\end{array}$

4.1.1.5 Section V: Cleaning 104

$\begin{array}{ll}\text { 4.1.1.5.1 Cleaning schedule documentation } & 105\end{array}$

4.1.1.5.2 Approved food grade detergents in use 105

4.1.1.5.3 Cleaning materials controlled including data sheets 105

4.1.1.5.4 Availability and condition of cleaning equipment and methods 106

$\begin{array}{lll}\text { 4.1.1.5.5 Separate areas for tray and equipment } & 106\end{array}$

$\begin{array}{lll}\text { 4.1.1.5.6 Adequate space for equipment to dry } & 107\end{array}$

$\begin{array}{lll}\text { 4.1.1.5.7 Training of cleaners } & 107\end{array}$

$\begin{array}{lll}\text { 4.1.1.5.8 Supervision and monitoring } & 107\end{array}$

4.1.1.5.9 Physical checks and bacteriological swabs taken 107

$\begin{array}{ll}\text { 4.1.1.5.10 Clean-as-you-go and good housekeeping } & 108\end{array}$

$\begin{array}{lll}\text { 4.1.1.6 Section VI: Pest control system } & 108\end{array}$ 
4.1.1.6.1 Special reporting type service $\quad 110$

4.1.1.6.2 Pest control records including bait plans, labels and dating $\quad 110$

4.1.1.6.3 Baiting and proofing standards including monitoring systems $\quad 111$

$\begin{array}{lll}\text { 4.1.1.6.4 Fly killer's position and condition } & 111\end{array}$

$\begin{array}{lll}\text { 4.1.1.6.5 Good perimeter controls } & 111\end{array}$

$\begin{array}{lll}\text { 4.1.1.6.6 Storage and housekeeping standards } & 111\end{array}$

4.1.1.7 Section VII: Personnel hygiene 112

$\begin{array}{lll}\text { 4.1.1.7.1 General } & 112\end{array}$

$\begin{array}{lll}\text { 4.1.1.7.2 } & \text { Health status } & 113\end{array}$

$\begin{array}{lll}\text { 4.1.1.7.3 Illness and injuries } & 113\end{array}$

$\begin{array}{lll}\text { 4.1.1.7.4 Personnel cleanliness } & 113\end{array}$

$\begin{array}{lll}\text { 4.1.1.7.5 Personnel behaviours } & 115\end{array}$

$\begin{array}{lll}\text { 4.1.1.7.6 Visitors } & 115\end{array}$

4.1.1.8 Section VIII: Quality assurance system 116

4.1.1.8.1 General 116

$\begin{array}{lll}\text { 4.1.1.8.2 } & \text { Finish product specifications } & 118\end{array}$

$\begin{array}{lll}\text { 4.1.1.8.3 Microbiological testing } & 118\end{array}$

$\begin{array}{lll}\text { 4.1.1.8.4 Temperature control } & 118\end{array}$

$\begin{array}{lll}\text { 4.1.1.8.5 Calibration } & 119\end{array}$

4.1.1.8.6 Product recall system $\quad 119$

4.1.1.8.7 The Traceability 119

4.1.1.8.8 The 5S applications in tea industry 119

4.2 Impact of HACCP based FSMS in Sri Lankan tea industry 121

$\begin{array}{ll}4.3 & \text { Food safety violations in low grown black tea industry } \\ & 125\end{array}$

$\begin{array}{ll}\text { 4.3.1 The Pareto analysis } & 125\end{array}$

$\begin{array}{ll}\text { 4.3.2 The Generic model development } & 128\end{array}$

4.4 5S Application and efficiency in tea industry 137

4.4.1 Synchronization of 5S with ISO 22000:2005 138

4.5 Traceability in orthodox black tea manufacturing process 148

4.6 Bridging the gap in fermentation 162

4.6.1 The tea polymerizer trolley - specifications 166

$\begin{array}{ll}\text { 4.6.2 Working of the equipment } & 167\end{array}$

$\begin{array}{lll}\text { 4.6.3 Inventions } & 168\end{array}$

4.6.4 TPT's advantages over current practices in tea fermentation $\quad 169$

$\begin{array}{ll}4.7 & \text { dissemination of information } \\ 4.8 & 170\end{array}$

$\begin{array}{lll}4.8 & \text { Limitation to the research } & 171\end{array}$

$\begin{array}{lr}\text { CHAPTER 5: CONCLUSION } & 173\end{array}$

$\begin{array}{ll}\text { RECOMMENDATION } & 178\end{array}$

$\begin{array}{lr}\text { REFERENCES } & 179\end{array}$ 


\section{APPENDICES}

Appendix I

List of Publications and Communications Made from Thesis

Appendix II

Separately Submitted

III

ISO 22000:2005 Food Safety Management System

A Generic Model for Black Tea Manufacturing

Appendix III

IV

GMP Evaluation I

$\mathrm{V}$

GMP Evaluation II

IX

Employee Knowledge Evaluation Questions

XIII

GMP Guidelines

XVI

ISO 22000 Gap Analysis Report Format

XXXVII

ISO 22000 FSMS Internal Audit Format

XLVII 


\section{LIST OF TABLES}

Table 4.1 Descriptive Statistics: O\&MR, ED\&F, SF, DF, Cleaning, PCS, PH, QAS, Total

Table 4.2 Spearman Rho: O\&MR, ED\&F, SF, DF, Cleaning,

PCS, PH, QAS, Total

Table 4.3: Impact of implementation of HACCP based FSMS on

food safety assurance of Sri Lankan in tea industry 


\section{LIST OF FIGURES}

Figure 2.1: Risk based management model (RBMM) 43

Figure 2.2: three layer model of ISO 22000:2005 44

Figure 2.3: ISO 22000 documentation pyramid 46

Figure 3.1: Open structure of the trolley $\quad 77$

Figure 3.2: Front view of a half section of the trolley 77

$\begin{array}{ll}\text { Figure 3.3: Single cage } & 78\end{array}$

Figure 3.4: Front view of a GN pan with holdup brackets on a cage 78

Figure 3.5: Two side holdup bracket $\quad 79$

Figure 3.6: Single side holdup bracket $\quad 79$

Figure 3.7: Perforated gastronome pan $\quad 79$

Figure 3.8: Records and hygrometer reading panel 79

Figure 4.1: Results achieved by individual tea factories $\quad 81$

Figure 4.2: Comparison of scores on factors considered for food safety 84 violations in low grown orthodox black tea manufacturing process

Figure 4.3: Statistical summary of organization and management responsibility $\quad 86$

Figure 4.4: Statistical summary of establishment design and facilities $\quad 87$

Figure 4.5: Compliance scores achieved in all tea factories of the sample 88

Figure 4.6: No proper scheduled cleaning for draining systems 91

Figure 4.7: Some of the poor floor conditions observed 93

Figure 4.8: Typical examples of ceilings \& lights at poorly scored factories $\quad 94$

Figure 4.9: Some of the water usage equipment, methods and gaps identified 96

Figure 4.10: Gaps identified in storage facilities 97

Figure 4.11: Statistical summary of storage facilities 98

Figure 4.12: Fermentation methods and their hygienic problems 99

Figure 4.13: Collection of GL and transport of made tea to the market 102

Figure 4.14: Statistical summary of distribution facilities 103

$\begin{array}{ll}\text { Figure 4.15: Statistical summary of cleaning } & 104\end{array}$

Figure 4.16: A typical cleaning method in operation 108

$\begin{array}{ll}\text { Figure 4.17: Summary statistics for pest control systems } & 109\end{array}$

Figure 4.18: Pest and the host animals are common in tea factories $\quad 110$

$\begin{array}{ll}\text { Figure 4.19: Bad personnel behaviours observed } & 114\end{array}$

$\begin{array}{ll}\text { Figure 4.20: Statistical summary of personnel hygiene } & 115\end{array}$

$\begin{array}{ll}\text { Figure 4.21: Statistical summary of quality assurance systems } & 117\end{array}$

Figure 4.22: Impact of HACCP based FSMS in Sri Lankan tea industry 122

Figure 4.23: Contribution of food safety violations from evaluated sectors $\quad 126$

Figure 4.24: Comparison of good manufacturing practices compliances $\quad 127$ and noncompliances

Figure 4.25: A possible approach to ISO 22000 decision tree model 133

$\begin{array}{ll}\text { Figure 4.26: } 5 \mathrm{~S} \text { adaptation in tea industry and success } & 137\end{array}$

Figure 4.27: Typical 5S Applications in Tea Industry 139 
Figure 4.28: Documentation Pyramid

Figure 4.29: One of the very good work instructions observed

During Evaluations

Figure 4.30: Constraints and compliances of traceability

in low grown orthodox black tea supply chain

Figure 4.31: Implementation probability of traceability

in low grown orthodox black tea supply chain

Figure 4.32: Graphical representation of generic process flow chart for the 1st dhool sifting program of orthodox black tea

Figure 4.33: Graphical representation of generic process flow chart for the 2nd and 3rd dhool sifting program of orthodox black tea

Figure 4.34: Graphical representation of generic process flow chart for the big bulk sifting program of orthodox black tea

Figure 4.35: A typical blending operation 160

Figure 4.36: Comparison temperature rise of TPT with other methods 164

Figure 4.37: Tea Polymerizer Trolley 166

Figure 4.38: The TPT operating at a production facility 168 


\section{ACKNOWLEDGEMENT}

At the outset of this thesis of a research endeavor conducted as a partial fulfillment of an M. Phil in Food Science and technology, first and foremost, I would like to thank my supervisors, Dr. Indira Wickramasinghe and Prof. K. K. D. S. Ranaweera for their help, guidance, and generous support throughout the course of my M. Phil study as well as for their assistance during the research formulation and conduct while providing rich knowledge of quality, safety and operational management and methodology approaches.

Also, I would like to thank Prof. S. B. Navaratne, for his invaluable advice for approaches and methods in research of food safety management system in the initial research stage.

I would like to thank Dr. Duminda Kuruppuarachchi for his invaluable assistance during the statistical analysis and selection of analysis methods.

I would especially like to express my gratitude to University of Sri Jayewardenepura for its support to enable me to do field work and collect data and information for this thesis and to the graduate administrative staff in the Faculty of Graduate Studies for their administrative support and help.

Several tea manufacturing organizations contributed non-financially to my research, and without them it would have been virtually impossible to complete this thesis. In addition, I would like to specially make my gratitude to Mr. M.R.M Rafi (Pathma Group), Mr. Manoj Wijekoon, Mr. M.M. Sumudu Priyanjith at Whilehena Tea Factory, without their support this research would have been an impossible task. I further extend my very special thanks to Mr. M.M. Sumudu Priyanjith for his invaluable knowledge, time and help rendered for the traceability studies and verification of various kinds of implementation documents. I also would like to extend further gratitude to Mr. Manoj Wijekoon for his invaluable support for implementation and maintenance as well as evaluation of the developed generic model.

I also deeply indebted to Mr. Jinadasa at Andaradeniya Group, Mr. Senevirathne at Mahaliyadda Tea Factory, Mr. Hasitha at Thalgasyaya Tea Factory and Mr. Shantha at Panilkanda Tea Factory for their support on conducting different research activities in their manufacturing facilities in addition to the participation of gap analysis and internal audits. The tea factory list is very longer but without their support, this work would have been not possible where my sincere thanks go to all persons including tea factory owners, tea factory officers, assistant factory officers, various kinds of operators participating in interviews, discussions and evaluations which further includes smallholding farmers, collectors, managers of companies and factories, auctioneers and auditors as well as quality officers. 
I'm deeply indebted to my friend Mr. Chandana Subasinghe at Subasinghe Technologist, who help me to carryout development of tea Polymerizer trolley at his workshop while providing invaluable technical inputs as well as carrying out the entire work under his supervision with financial support, without your help it was unachievable my friend.

I specially thank to Mr. Sumith Ponnamperuma, Mr. Supun Jayasinghe and Mr. W. Sampath at Control Union for their assistance in auditing and improvement suggestions for the generic model. The same gratitude goes to Mr. Nishantha Subasinghe at Bureau Veritas for auditing and certifying the developed generic model with improvement suggestions.

I also would like to sincerely thank Mr. Keerthi Bandara Karunarathne for his invaluable support and encouragement for improving and developing the two blog pages particularly ISO 22000 Resource Center and Tea Quality Center.

I sincerely thanks to academic staff, nonacademic staff, colleagues, and friends in Department of Food science, Faculty of Applied Science, University of Sri Jayewardenepura for giving me support, encouragement, and sharing knowledge and wisdom of completing this work.

Further thanks to my supervisors who always encourages me to follow a research degree instead of following a thought course and to get into scientific research. You are my pride, and give me advice and wisdom.

I also like to thanks my last two employers, Lanka Spice (Pvt) Ltd and C. D. De Fonseka and Sons (Pvt) Ltd, for their patience, support and going with me throughout the difficult period of doing the research and writing a thesis.

Finally but most importantly, I devote the deepest gratitude to my family Dad, Mum, Sister and Brothers for their unfailing love, spirit, encouragement and support.

University of Sri Jayewardenepura

December 2015 


\section{ABBREVIATIONS}

AFO

BRC

C-FSMS

CCP

$\mathrm{CL}$

COP

CSR

CTC

D. Ref

D/GM

DF

ED\&F

ETP

F

FO

FR

FSMS

FSP

FSTL

GAP

GHP

GI

GMP

HA

HACCP

$\mathrm{HI}$

ISO

NCR

O\&MR

OPRP

$\mathrm{P}$

PCS

PH

PR

PRP

QAS

RA

RBMM

RM

RP

RR

$\mathrm{S}$

SF

$\mathrm{SR} / \mathrm{GR}$

SV

TP

TPT

TQM

WA

WI
Assistant Factory Officer

British Retailer's Consortium

Consultant - Food Safety Management System

Critical Control Point

Checklist

Cost of Production

Corporate Social Responsibility

Cut, Tear and Curl

Document Reference

Director/General Manager

Distribution Facilities

Establishment Design and Facilities

Ethical Tea Partnership

Format/Form

Factory Officer

Firing Room

Food Safety Management System

Food safety procedure

Food Safety Team Leader

Good Agricultural Practices

Good Hygienic Practices

Guide

Good Manufacturing Practices

Hazard Analysis

Hazards Analysis Critical Control Point

Hazard Identification

International Standardization Organization

Nonconformity Report

Organization and Management Responsibility

Operation Perquisite Programmes

Prevalence

Pest Control Systems

Personal Hygiene

Packing Room

Perquisite Programmes

Quality Assurance Systems

Risk Assessment

Risk Based Management Model

Raw Material

Risk Profile/Report

Rolling Room

Severity

Storage Facilities

Sifting Room/Grading Room

System Validation

Test Procedure

Tea Polymerizer Trolley

Total Quality Management

Withering Area

Work Instructions 


\begin{abstract}
Tea is the most commonly drunk beverage in the world and the second most important drink after water. Sri Lanka accounts for $9 \%$ share of the world tea production and produces about 320 million kilograms of made tea. Sri Lanka is still the market leader for orthodox black tea. As Sri Lankan tea industry is highly export driven trade, it is necessary to satisfy demands set for statutory, regulatory, social and environmental responsibilities throughout the supply chain. Likewise, safety of food commodities including tea is a global phenomenon growing its importance everyday due to the concerns in public health and impact on global trade.
\end{abstract}

A study was carried out to identify and assess the major food safety violations occurring in manufacturing process of low grown orthodox black tea, while identifying the food safety measures satisfy ISO 22000 requirements. Stratified disproportional random sampling was used where qualitative data was weighted averaged against GMP requirements and converted in to quantitative values to be used in statistical analyses. All stakeholders in tea manufacturing process were interviewed through the gap analysis and internal audits. The impact of HACCP based FSMS on improving food safety was evaluated and new hybrid documentation system was developed. The document system developed was improved based on the audit findings and real time application in industry as a user innovation strategy where progressive changes were incorporated to the design. In addition, traceability practices and their compliances were examined, while proposing possible solutions for identified major drawbacks. The traceability was evaluated using a checklist, end product sampling, open ended interviews, observations and internal document studies. Accordingly, an extended gap was observed in tea fermentation process without proper equipment and appropriate technologies to provide better hygienic conditions and optimum environment for tea polymerization where a prototype was developed to bridge the gap. Further, information availability for adequate food safety systems was rarely available. Webpages were developed to bridge the information gap. As to the results, average compliance levels achieved in the area of GMP on the reference sample was $68.81 \%$ due to the incomplete system developments, lack of expert knowledge in the industry and also due to the inappropriate practices. The organization and management responsibility was strongly correlated with Establishment Design and Facilities while quality assurance systems became the second contributor. Further, Quality Assurance Systems had a strong to moderate correlation with all the factors. Pest Control Systems had the weakest correlation to improvement of food safety. Personal 
Hygiene was not satisfactorily developed. Thus Establishment Design and Facilities were the major root cause for food hygiene problems identified, where storage facilities were also affected due to the same problem. Conditions and processing operations that were connected with the fermentation were found very unhygienic in manufacturing orthodox black tea. Thus continuous attention and top management commitment with additional capital investments were found crucial in improving design and facilities. It was also found that quality assurance systems were not adequately developed and implemented, which was the root cause for hygienic problems in tea industry. HACCP based food safety systems have enabled an environment to improve GMP tools where factories with HACCP based FSMS had better infrastructure and systematic operations with trained operators. The efficiency of processing, recording and personnel hygiene were satisfactorily improved in factories with $\mathrm{HACCP}$ and $5 \mathrm{~S}$, where $5 \mathrm{~S}$ has played a major role in improving infrastructure and training of workers. Based on the above analyses, the generic model was developed to bridge the gaps in quality assurance, which is a user friendly customizable paper based model along with required documents and formats. The operator level documents were prepared in local language and 5S work instructions were enriched with food hygiene requirements instead of developing a new set of work instructions where harmonization, modification and adaptation were found very effective. Synchronization reduced the number of documents used in FSMS and frequency of recording to a greater extent while improving the effectiveness of recording.

Major traceability issues were first observed in leaf collection which was caused due to the involvement of smallholder growers. This was intensified in grading operations due to complexity of separation and small specific amounts produced. Bulking and blending process further extended complexity. Increased number of suppliers led to increased mixing of different made tea. In such situations, traceability up to tea bush, grading, blending and traceability of end product back to supplier were not fully complying. Nevertheless, supplier records, traceability after packaging, at dispatch and after dispatch were in full compliance. Other factors had varying degree of compliances which make the complete traceability unachievable. The development of fermentation trolley used food grade stainless steel gastronome pans on a stainless steel trolley rack with easy cleaning and added features for systematic handling. It reduced the risk of contamination while reducing heat build-up in the product for required conditions. Results revealed that temperature build-up on Tea Polymerizer Trolley, can remarkably reduce to the optimum levels than do plastic crates and tiled floor. 